УДК 681.51

DOI https://doi.org/10.32838/2663-5941/2020.5/13

\title{
Кірсанов В.В.
}

Національна металургійна академія України

Рибальченко М.O.

Національна металургійна академія України

\section{Шибакінський В.I.}

Національна металургійна академія України

\section{Михайловський М.В.}

Національна металургійна академія України

\section{ОПТИМІЗАЦІЯ КОМБІНОВАНОЇ АСР ДЕЯКИХ ПАРАМЕТРІВ БАРАБАННИХ КОТЛІВ}

Одне з основних завдань управління технологічним прочесом на тепловій електростаниії (ТЕС) складається в підтримиі безперервної відповідності між кількостями виробленої і споживаної енерzіï. Вирімення цього завдання може здійснюватись за допомогою автономних автоматичних систем регулювання (ACP) параметрів парового котла, турбіни і електричного генератора. Ці системи виконують безперервне і досить якісне регулювання окремих технологічних процесів, але не призначені для рімення завдань оптимізаиії по енергоблоку в иілому.

У статті розглянуто наявні автоматичні системи регулювання (АСР) рівня та розрідження барабанних котлів, таких як ДКВР-10-13. Встановлено, що для попередження частого виникнення значного матеріального небалансу між паливом та повітрям, що нагнітається в топку, $і$ виходячими з топки димовими газами та витратою поступаючої живильної води і витратою пари, ще надходить до споживача, підвищення швидкодії та надійності регулювання основного параметр, пропонується вводити в регулятор додаткову дію в залежності від зміни основного збурення (компенсатор збурення). Згідно із иією рекомендацією розроблена комбінована АСР, в якій одночасно використовується принщип регулювання по відхиленню та збуренню.

Для підтвердження правильності вибору закону регулювання $і$ параметрів регулятора та компенсатора, на прикладі АСР рівня виконано моделювання в пакеті прикладних програм MATLAB/Simulink. Використання каналу компенсації основного збурення поліпшує якість підтримки технологічного параметру в заданих межсах при виникненні значних збурюючих дій. Таким чином, отримані результати моделювання підтверджують ефективність комбінованої системи, розробленої в роботі.

Ключові слова: автоматична система регулювання, барабанний котел, рівень, розрідження, збурення, якість, моделювання

Постановка проблеми. Одне 3 основних завдань управління технологічним процесом на теплових електростанціях (ТЕС) полягає в підтримці безперервної відповідності між кількостями виробленої і споживаної енергії. Рішення цього завдання може здійснюватись за допомогою автономних АСР параметрів парового котла.

Аналіз останніх досліджень і публікацій. Основними регульованими величинами котла $\epsilon$ витрата $\mathrm{F}_{\text {пा }}$, тиск $\mathrm{P}_{\text {пा }}$ i температура $\mathrm{T}_{\text {пा }}$ перегрітої пари. Крім того, необхідно підтримувати в межах припустимих відхилень значення деяких інших параметрів, серед найважливіших 3 яких є рівень води у барабані котла L, розрідження у верхній частині топки $\mathrm{P}_{\text {т }}$ які забезпечують умови нормального теплового режиму та $є$ непрямими показниками матеріального балансу [1].

Наявні АСР рівня та розрідження виконані, як правило, за принципом комбінованого регулювання, реалізовані на застарілій елементній базі і мають низьку надійність. Крім того, вони не дозволяють застосовувати більш удосконалені алгоритми функціонування 3 метою компенсації збурюючих впливів залежно від теплової потужності агрегату.

При високих вимогах до якості стабілізації керованих величин практично неможливо досягти повної ліквідації відхилення їх від заданого 
значення в одноконтурній системі. Це пояснюється тим, що спроба збільшення коефіцієнта підсилення регулятора $з$ метою підвищення точності системи призводить до погіршення та майже втрати системою стійкості.

Постановка завдання. Тому для попередження частого виникнення значного матеріального небалансу між паливом та повітрям, що нагнітається в топку, і виходячими 3 топки димовими газами та витратою поступаючої живільної води і витратою пари, що надходить до споживача, підвищення швидкодії та надійності регулювання основного параметра пропонується вводити в регулятор додаткову дію в залежності від зміни основного збурення (компенсатор збурення) [2].

Виклад основного матеріалу дослідження. Спрощені схеми систем регулювання рівня живільної води та розрідження в топці котла наведені на рисунках 1 та 2 відповідно.

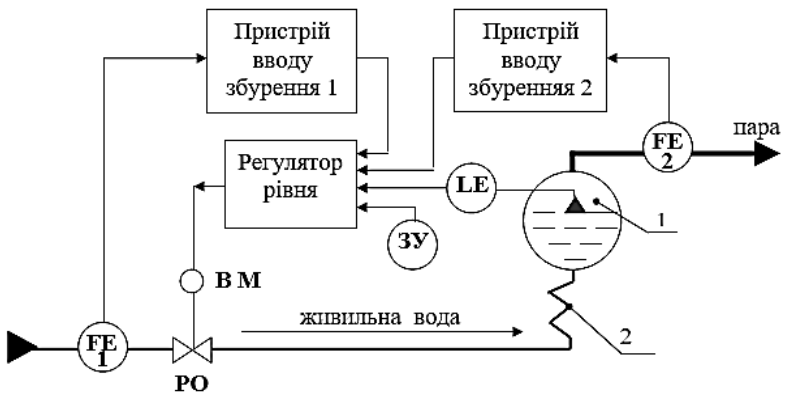

Рис. 1. Спрощена схема комбінованої АСР живлення водою парового котла: 1 - барабан; 2 д - економайзер

На рис. 1 регулятор рівня переміщає регулючий орган $\mathrm{PO}$ при відхиленнях рівня L від заданого значення. Крім того, він переміщує регулючий клапан живильної води під час появи сигнала небалансу між витратами живильної води і пари, підтримуючи незмінність їх співвідношення.

На рис. 2 включення регулятора повітря 3 призводить до тимчасового порушення матеріального балансу між повітрям, що поступає в топку котла, і димовими газами, що йдуть 3 неї.

Для попередження виникнення такого небалансу і збільшення швидкодії регулятора розрідження в нього вводиться додаткова зникаюча дія від регулятора повітря 3 або датчика витрати повітря через пристрій динамічного зв'язку 2 (компенсатор збурення).

У випадку відхилення поточного значення розрідження в топці котла від заданого регулятор впливає через блок логічного управління БЛУ на управні частотні перетворювачі УЧП1 і УЧП2 привода робочого колеса димососів «А» $\mathrm{i}$ «Б», що змі- нює кількість димових газів, що йдуть, доти, поки розрідження не досягне заданого значення. БЛУ впливає на УЧП1 або УЧП2, або разом на них залежно від частоти обертання приводів крильчатки димососів.

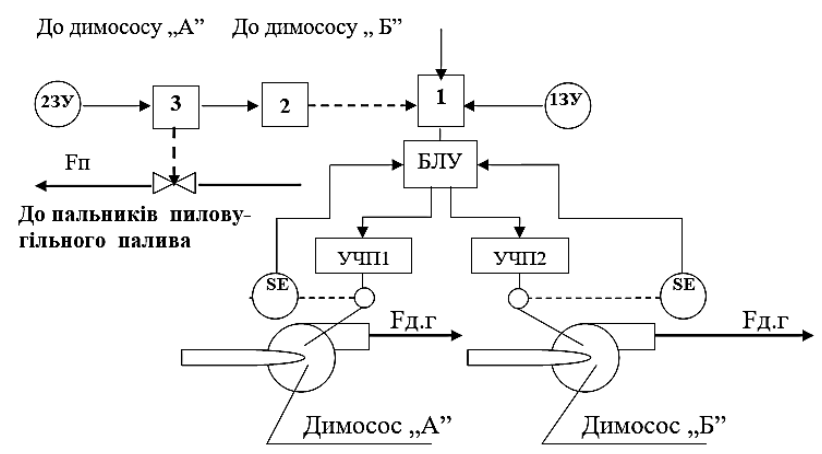

Рис. 2. Спрощена схема комбінованої АСР розрідження в топці: 1, 3 - відповідно регулятори розрідження і витрати загального повітря на топку; 13У, 23У - задатчики відповідно розрідження і витрати загального повітря;

2 - компенсатор збурення; БЛУ - блок логічного управління; УЧП - управний частотний перетворювач привода крильчатки димососа; Fд.г., Fв - витрати димових газів і повітря

Найбільш вагомим збурюючим впливом $\epsilon$ витрата повітря, зміна якої відбувається при зміні теплового навантаження котла, особливо в режимі регулювання. Для виключення впливу цього збурення на розрідження використовуємо компенсатор, на вхід якого надходять сумарні витрати повітря на пальники пиловугільного палива. Вихідний сигнал компенсатора в управляючому обчислювальному комплексі УОК формує додаткову управляючу дію регулятора розрідження.

Регулятор розрідження складається 3 одного контуру регулювання і його управляючий вплив подається на той привід робочого колеса димососа, частота обертання якого менше. Такий підхід до управління розрідженням в топці дозволяє додатково економити електроенергію, яка використовується на створення у димовідводячому тракті тяги. У тому випадку, коли обидва приводи крильчатки димососів «А» и «Б» мають однакову швидкість, управляючий вплив 3 виходу регулятора розрідження подається на обидва приводи крильчатки одночасно, але 3 коефіціентом передачі, який дорівнює 0,5.

У наведених комбінованих системах є принципова можливість забезпечення інваріантності регульованої величини до тих збурень, які вимірюються, і додаткові впливи від яких вводяться в систему. 
Для реалізації такої можливості потрібно правильно розрахувати як параметри основного регулятора, так і компенсатора збурень. Тому питання розрахунку передатних функцій компенсаторів потребують подальшого розглядання.

Параметри регулятора рівня розраховуємо, виходячи з того, що об'єкт регулювання є інтегруючою ланкою. Тому з урахуванням інерційності виконавчого механізму i регулюючого органа передатна функція каналу «небаланс витрати води і пари - рівень у барабані» має вигляд:

$$
\mathrm{Woy}(\mathrm{p})=\frac{\mathrm{L}(\mathrm{p})}{\mathrm{U}(\mathrm{p})}=\frac{1}{\mathrm{Tp} \cdot(\mathrm{T} \mu \mathrm{p}+1)},
$$

де Woy(p) - передатна функція об'єкта по управляючому впливу;

$\mathrm{L}(\mathrm{p}), \mathrm{U}(\mathrm{p})$ - зображення відхилення рівня від завдання і зображення управляючого впливу (\% ходу ВМ) відповідно;

Т, Т $\mu$ - постійні часу об'єкта.

Маючи передатну функцію об'єкта (1) для визначення структури і параметрів автоматичного регулятора рівня, доцільно використовувати метод аналітичного конструювання регуляторів (АКОР) [2].

Для цього на підставі передатної функції (1) записуємо рівняння об’єкта у формі «вхід-вихід»:

$$
\mathrm{T} \cdot \mathrm{T} \mu \frac{\mathrm{d}^{2} \mathrm{~L}}{\mathrm{dt}^{2}}+\mathrm{T} \frac{\mathrm{dL}}{\mathrm{dt}}=\mathrm{U} .
$$

Для застосування методу АКОР перейдемо від рівняння (2) до рівнянь стану об'єкта. Для цього введемо в розгляд двомірний вектор стану $x$ з координатами $\mathrm{L}=x_{1} ; \mathrm{L}=x_{1}=x_{2}$ і розв'язуємо рівняння (2) щодо старшої похідної:

$$
\begin{array}{r}
\frac{\mathrm{d}^{2} \mathrm{~L}}{\mathrm{dt}^{2}}=-\mathrm{a}_{1} \frac{\mathrm{dL}}{\mathrm{dt}}+\mathrm{b}_{\mathrm{o}} \cdot \mathrm{U}, \\
\text { де } \mathrm{a}_{1}=\frac{\mathrm{T}}{\mathrm{T} \cdot \mathrm{T} \mu}=\frac{1}{\mathrm{~T} \mu} ; \mathrm{b}_{\mathrm{o}}=\frac{1}{\mathrm{~T} \cdot \mathrm{T} \mu} .
\end{array}
$$

Тоді $\mathrm{L}=x_{1} ; \mathrm{L}=x_{1}=x_{2}$ і рівняння стану об'єкта приймає вид:

$$
\left.\begin{array}{c}
\dot{x}_{1}=x_{2} ; \\
\dot{x}_{2}=-\mathrm{a}_{1} x_{2}+\mathrm{b}_{0} \mathrm{U} ; \\
\mathrm{L}=X_{1} ; x_{2}(0)=\dot{\mathrm{L}}(0) \quad x_{1}(0)=\mathrm{L}(0) .
\end{array}\right\}
$$

Потрібно синтезувати оптимальне управління $\mathrm{U}^{*}$, яке об' єкт управління (4) переводить із початкового положення $x_{1}(0), x_{2}(0)$ у кінцеве положення $x_{1}(\infty)=x_{2}(\infty)=0$, так щоб квадратичний інтегральний критерій якості

$$
\mathrm{J}=\int_{0}^{\infty}\left(\mathrm{q}_{1} X_{1}^{2}+\mathrm{q}_{2} X_{2}^{2}+\mathrm{r} \cdot \mathrm{U}^{2}\right) \mathrm{dt},
$$

де: $\mathrm{q}_{1} \geq 0 ; \mathrm{q}_{2} \geq 0 ; \mathrm{r}>0$ - вагові коефіцієнти) прийняв мінімальне значення.

У загальному випадку оптимальне управління $\mathrm{U}^{*}$ об'єктом (4), що доставляє мінімум критерію (5), має вигляд [3]:

$$
\mathrm{U}^{*}=-\mathrm{K}_{1 \mathrm{P}} \mathrm{X}_{1}-\mathrm{K}_{2 \mathrm{P}} \mathrm{X}_{2},
$$

де $\mathrm{K}_{1 \mathrm{P}}, \mathrm{K}_{2 \mathrm{p}}$ - коефіціснти підсилення регулятора, що залежать від параметрів об'єкта $\mathrm{a}_{1}$, $\mathrm{b}_{\mathrm{o}}$ i вагових коефіцієнтів $\mathrm{q}_{1}, \mathrm{q}_{2}, \mathrm{r}$.

Структурна схема оптимальної системи, яка побудована на підставі системи рівнянь стану об'єкта управління (4) і регулятора (6) наведена на рис. 3.

Структурну схему (рис. 3) перетворимо в одноконтурну АСР рівня, тому що реально ми вимірюємо тільки рівень води в барабані котла. Ця схема наведена на рис. 4.

Як бачимо 3 рисунку 4 регулятор рівня води в барабані котла $є$ ПД-регулятором:

$$
\mathrm{W}_{\mathrm{AP}}(\mathrm{p})=\mathrm{K}_{\mathrm{P}}\left(\mathrm{T}_{\mathrm{A}} \cdot \mathrm{p}+1\right),
$$

де $\mathrm{K}_{\mathrm{P}}=\mathrm{K}_{1 \mathrm{P}}, \mathrm{T}_{\mathrm{z}}=\frac{\mathrm{K}_{2 \mathrm{P}}}{\mathrm{K}_{1 \mathrm{P}}}-$ відповідно коефіцієнт підсилення і постійна часу диференціювання регулятора.

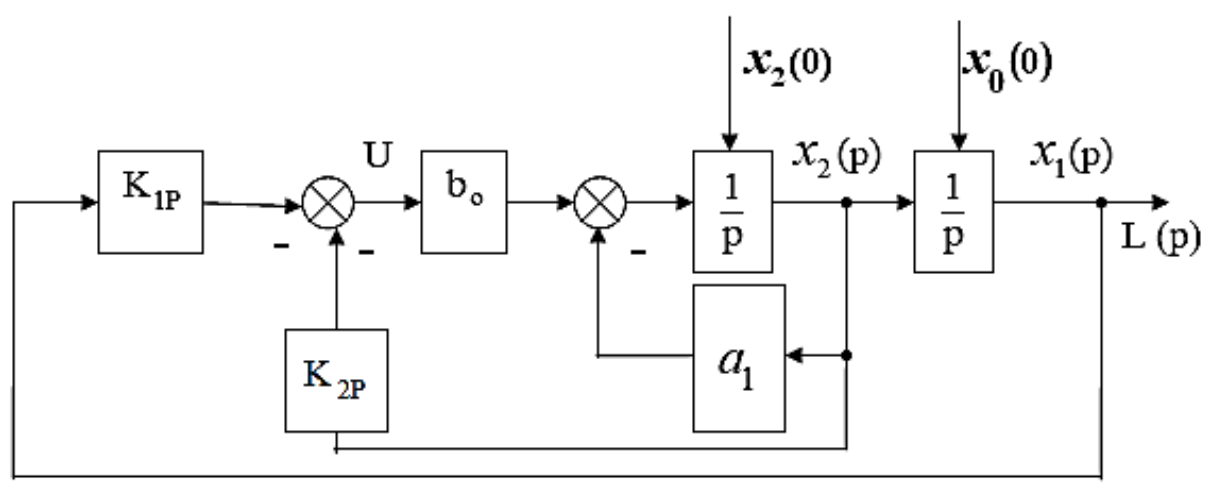

Рис. 3. Структурна схема оптимальної АСР рівня 
Якщо вибрати постійну часу диференціювання регулятора $\mathrm{T}_{\text {д }}=\mathrm{T}_{\mu}$, а коефіцієнт підсилення регулятора $з$ умови забезпечення необхідної статичної точності системи по збурюванню, то перехідні процеси в АСР рівня будуть аперіодичними, такі ж, як в аперіодичній ланці 1-го порядку. Для визначення передатних функцій пристроїв введення збурень на рис. 5 наведена структурна схема комбінованої АСР рівня, яка побудована згідно з рисунком 1.

На рисунку Wзі(p) - передатна функція об'єкта регулювання по і-ому збуренню Fi(p); Wki(p) передатна функція компенсатора і-ого збурення.

На підставі структурної схеми (рис. 5) можна записати вираз для зображення рівня L(p):

$$
\mathrm{L}(\mathrm{p})=\frac{\mathrm{W}_{\mathrm{AP}}(\mathrm{p}) \cdot \mathrm{W}_{\mathrm{oy}}(\mathrm{p})}{1+\mathrm{W}_{\mathrm{AP}}(\mathrm{p}) \cdot \mathrm{W}_{\mathrm{Oy}}(\mathrm{p})} \cdot \mathrm{L}_{3}(\mathrm{p})+\frac{\mathrm{W}_{3 \mathrm{i}}(\mathrm{p})-\mathrm{W}_{\mathrm{ki}}(\mathrm{p}) \cdot \mathrm{W}_{\mathrm{AP}}(\mathrm{p}) \cdot \mathrm{W}_{\mathrm{oy}}(\mathrm{p})}{1+\mathrm{W}_{\mathrm{AP}}(\mathrm{p}) \cdot \mathrm{W}_{\mathrm{oy}}(\mathrm{p})} \cdot \mathrm{Fi}(\mathrm{p})
$$

Ця формула може бути переписана в такому вигляді:

$$
\mathrm{L}(\mathrm{p})=\mathrm{W}_{3 . c .}(\mathrm{p}) \cdot\left[\mathrm{L}_{3}(\mathrm{p})+\mathrm{W} 3 \mathrm{i}(\mathrm{p}) \cdot \mathrm{F}_{\mathrm{i}}(\mathrm{p})\right] .
$$

При такому запису структурна схема системи по рис. 5 може бути замінена структурною схемою, наведеною на рис. 6, де частина системи 3 передатною функцією замкненої системи по управляючому впливу

$$
\mathrm{W}_{3 . c .}(\mathrm{p})=\frac{\mathrm{W}_{\mathrm{AP}}(\mathrm{p}) \cdot \mathrm{W}_{\mathrm{oy}}(\mathrm{p})}{1+\mathrm{W}_{\mathrm{AP}}(\mathrm{p}) \cdot \mathrm{W}_{\mathrm{oy}}(\mathrm{p})}
$$

визначає стійкість, а частина системи 3 передатною функцією

$$
\mathrm{W}_{3 в \mathrm{i}}(\mathrm{p})=\frac{\mathrm{W}_{3 \mathrm{i}}(\mathrm{p})}{\mathrm{W}_{\mathrm{AP}}(\mathrm{p}) \cdot \mathrm{W}_{\text {оy }}(\mathrm{p})}-\mathrm{W}_{\mathrm{ki}}(\mathrm{p})
$$

$\epsilon$ фільтром, через який проходить i-е збурення, перш ніж увійти на вхід регулятора у вигляді управляючого впливу.

Як бачимо з рівняння (10), передатна функція обладнання введення впливів по збуренням не входить у вираз для передатної функції замкненої системи, тому збільшення точності роботи системи можна робити, не впливаючи на iii стійкість. Зокрема, якщо передатну функцію обладнання введення, довільного і-ого збурення вибрати з умови

$$
\mathrm{W}_{\mathrm{ki}}(\mathrm{p})=\frac{\mathrm{W}_{3 \mathrm{i}}(\mathrm{p})}{\mathrm{W}_{\mathrm{AP}}(\mathrm{p}) \cdot \mathrm{W}_{\mathrm{oy}}(\mathrm{p})},
$$

тоді, з формул (8) і (11) випливає, що відхилення регульованої величини при дії цього збурення буде зовсім відсутне, тому що фільтр у цьому випадку зовсім не пропускає впливів.

Рівняння (12) є умовою абсолютної інваріантності регульованої величини щодо обраного і-ого, збурюючого впливу.

Згідно 3 попередніми міркуваннями структурна схема АCР розрідження у топці котла, в якій основним збурюючим впливом $є$ витрата повітря,

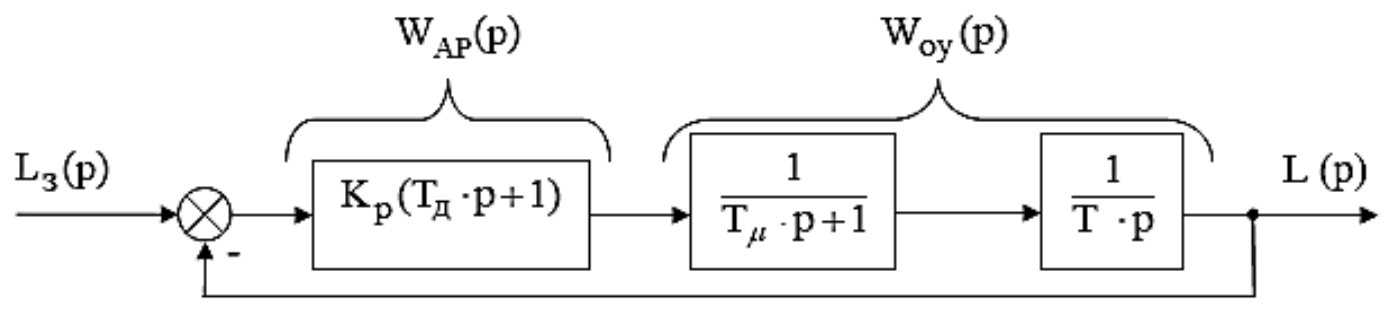

Рис. 4. Структурна схема оптимальної одноконтурної АСР рівня

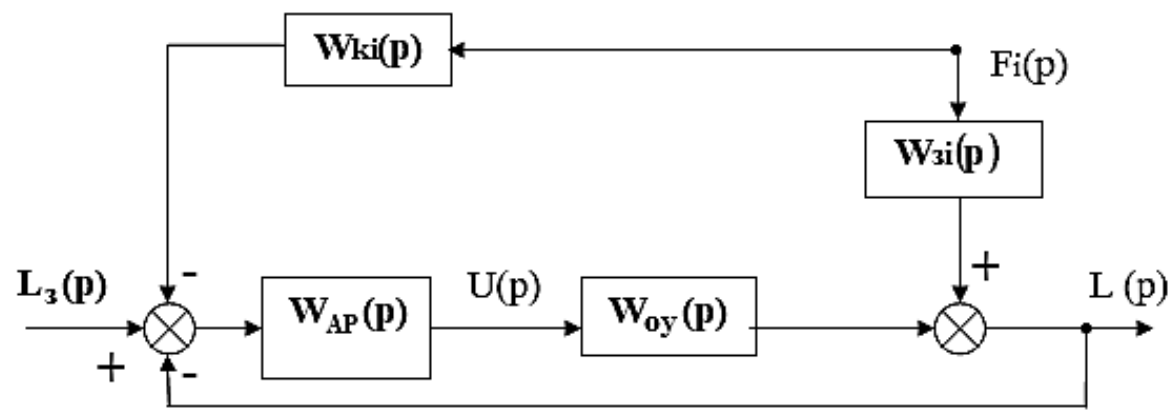

Рис. 5. Структурна схема АСР рівня з подачею додаткового впливу від i-го збурення на вхід регулятора $(\mathrm{i}=1,2)$ 
наведена на рисунку 7 , тобто вона аналогічна схемі (рис. 5).

Тому усі положення та вирази відносно АСР рівня стосуються і АСР розрідження.

Якщо регулятор розрідження є ПІ -регулятором $з$ передатною функцією

$$
\mathrm{W}_{\mathrm{P}}(\mathrm{p})=\mathrm{Kp}\left(1+\frac{1}{\operatorname{Tup}}\right)=\frac{\mathrm{Kp}(\mathrm{Tup}+1)}{\text { Tup }},
$$

а передатні функції об'єкта з управління і збурюючих дій однакові, тобто $\mathrm{W}_{\mathrm{OB}}(\mathrm{p})=\mathrm{W}_{\text {оу }}(\mathrm{p})$, то згідно 3 рівнянням (12) передатна функція компенсатора $\mathrm{W}_{\mathrm{K}}(\mathrm{p})$ дорівнює:

$$
\mathrm{W}_{\mathrm{K}}(\mathrm{p})=\frac{1}{\mathrm{~W}_{\mathrm{P}}(\mathrm{p})}=\frac{\mathrm{T}_{\mathrm{u}} \mathrm{p}}{\mathrm{Kp}(\mathrm{Tup}+1)} .
$$

Таким чином, для виключення впливу на розрідження коливання витрати повітря, що поступає в топку котла, компенсатор має бути реальною диференцуючою ланкою.

Для підтвердження правильності вибору закону регулювання і параметрів регулятора і компенсатора на прикладі АСР рівня виконано моделювання в пакеті прикладних програм MATLAB.

Під час дослідження цієї системи прийняті наступні параметри об'єкта: $\mathrm{T}_{\mu}=1,5 \mathrm{c} ; \mathrm{T}=10 \mathrm{c}$. [4]. Параметри регулятора обрані з умови компенсації $\mathrm{T}_{\propto}$ i його передатна функція дорівнює $\mathrm{W}_{\mathrm{AP}}(\mathrm{p})=\mathrm{K}_{\mathrm{p}} \cdot\left(\mathrm{T}_{\text {д }} \mathrm{p}+1\right)$, тобто маємо ПД - регулятор: $\mathrm{T}_{\text {म }}=1,5 \mathrm{c} ; \mathrm{K}_{\mathrm{p}}=50$.
Під час моделювання завдання змінювали стрибкоподібно на $\mathrm{L}=20 \mathrm{Mм}$, а після закінчення перехідних процесів регулювання, через 2 с., стрибкоподібно змінювали основне збурення (витрата пари) на 20\%.

Результати моделювання одноконтурної АСР рівня води наведені на рисунку 8 .

Перехідні процеси мають аперіодичний характер. Тривалість перехідного процесу за завданням не перевищує 1 с, а по збуренню 3 с. Статична помилка становить 0,4 мм, або у відсотках $\Delta \mathrm{L}=\frac{0,4}{20} \cdot 100 \%=2 \%$. Для іiі зменшення слід збільшувати коефіцієнт підсилення регулятора $\mathrm{K}_{\mathrm{p}}$.

Як було показано вище, найбільш ефективним способом усунення впливу збурень у вигляді змін витрат пари i живильної води є введення цих впливів через компенсатори на вхід регулятора.

Схема моделювання комбінованої АСР рівня наведена на рис. 9.

Як видно з рисунку 9, рівень води в барабані котла не залежить від витрати пари. Це підтверджує ефективність комбінованої системи.

Висновки. Отримані умови інваріантності рівня води в барабані щодо витрат живильної води і пари на виході котла як основних збурюючих впливів. Подібні умови стосуються і регулювання розрідження в топці котла. Дослідження комбінованої АCР рівня показало можливість повністю усунути вплив змін витрат води і витрат пари на рівень води в барабані, що підтверджує високу ефективність роботи системи.

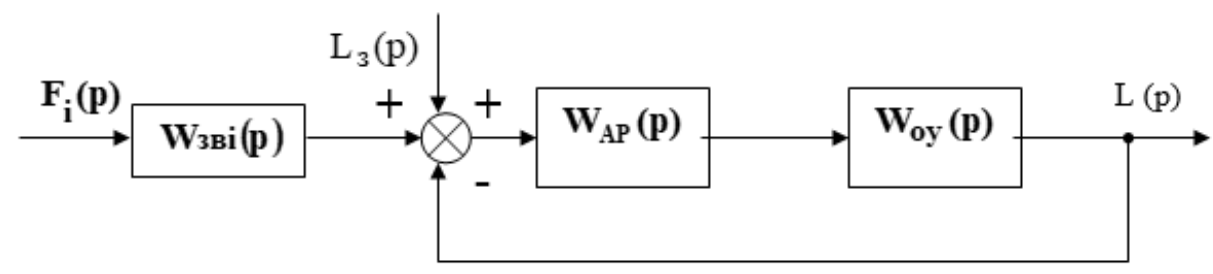

Рис. 6. Наведена до одного входу структурна схема комбінованої АСР рівня

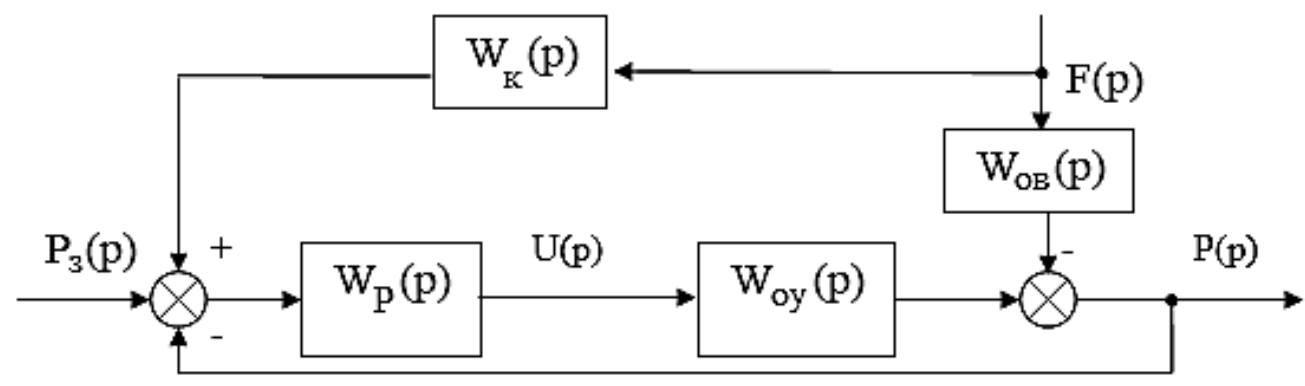

Рис. 7. Структурна схема комбінованої АCP розрідження: Woy(p), Woв(p) - передатні функції об' скту по управляючому і збурюючому впливам; $W_{\mathrm{P}}(\mathrm{p})$ - передатна функція регулятора; $W_{\mathrm{K}}(\mathrm{p})$ передатна функція компенсатора; $\mathrm{P}, \mathrm{P} 3$ - поточне значення розрідження і його завдання; F- витрата повітря 


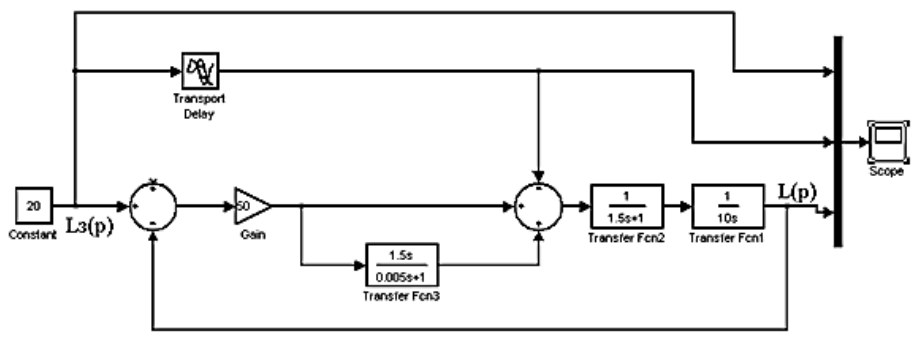

a)

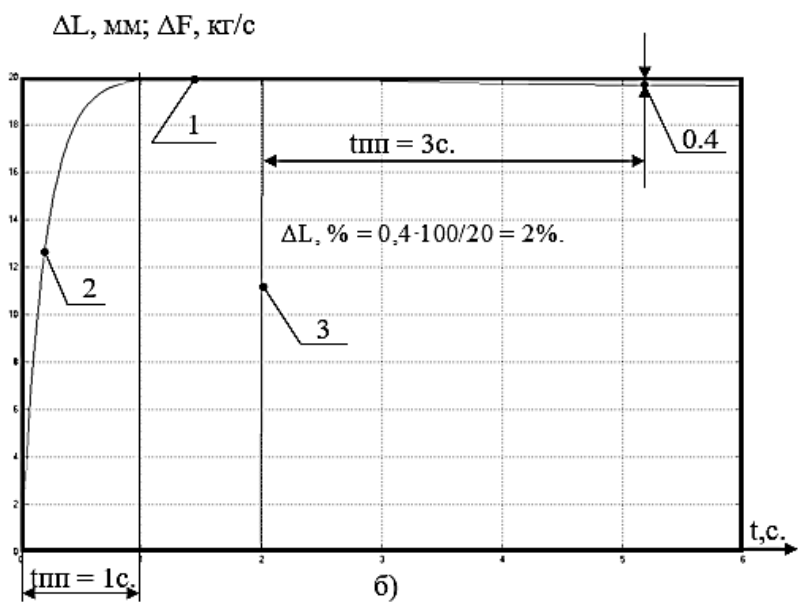

Рис. 8. Схема моделі одноконтурної АСР рівня води (а) та перехідні процеси регулювання в цій системі (б): 1, 3 - стрибкоподібна зміна завдання та збурення; 2 - крива зміни рівня води

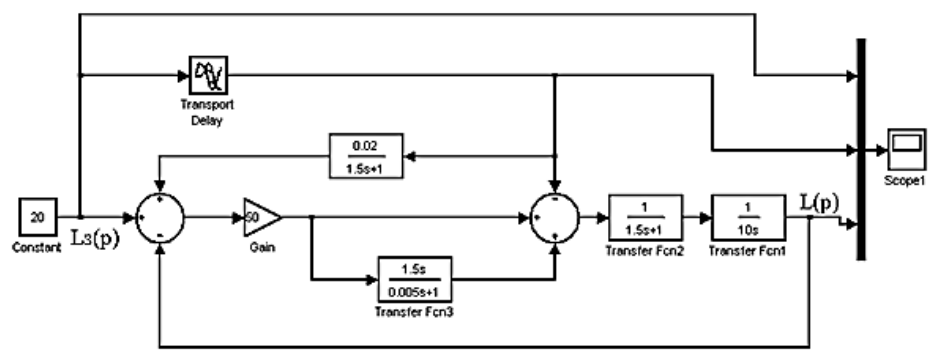

$\Delta \mathrm{L}, \mathrm{MM} ; \Delta \mathrm{F}, \mathrm{Kr} / \mathrm{c}$

a)

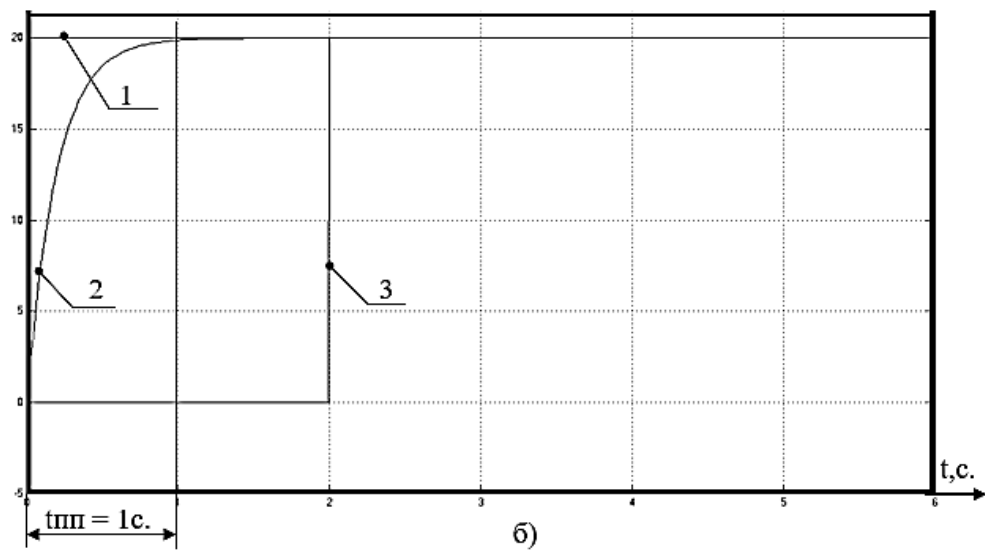

Рис. 9. Схема моделі АСР рівня води при наявності контуру компенсації (а) та перехідні процеси в цій системі (б): 1, 3 - стрибкоподібна зміна завдання та збурення; 2 - крива зміни рівня води 


\section{Список літератури:}

1. Плетнев Г.П. Автоматизированное управление обьектами тепловых электростанций. Москва : Энергоатомиздат, 1981. $365 \mathrm{c.}$

2. Система автоматического регулирования уровня в барабане котла: а.c. SU 1760242 A1: MПК F 22 D 5/30. № 4822047/06; заявл. 25.01.90; опубл. 07.09.92, Бюл. № 33.12 с.

3. Кирсанов В.В., Михайловский Н.В., Потап О.Е. Оптимальные системы автоматического управления. Дніпро : НметАУ, 2019. 319 с.

4. Плетнев Г.П. Автоматическое управление и защита теплоэнергетических установок электростанций : учебник для техникумов. Москва : Энергоатомиздат, 1986. 344 с.

\section{Kirsanov V.V., Rybalchenko M.O., Shybakinskyi V.I., Mykhailovskyi M.V. OPTIMIZATION OF THE COMBINED AUTOMATIC CONTROL SYSTEM OF SOME PARAMETERS OF DRUM BOILERS}

One of the main tasks of process control at a thermal power plant is to maintain a continuous correspondence between the amounts of energy produced and consumed. The solution of this problem can be carried out by means of autonomous automatic control systems of parameters of a steam boiler, the turbine and the electric generator. These systems perform continuous and high-quality regulation of individual technological processes, but are not designed to solve optimization problems for the power unit as a whole.

The article considers the existing automatic systems for regulating the level and vacuum of drum boilers, such as DKVR-10-13. It is established that in order to prevent the frequent occurrence of significant material imbalance between fuel and air injected into the furnace and flue gases leaving the furnace and the flow of incoming feed water and steam flow to the consumer, increase the speed and reliability of control of the main parameter in the regulator additional action depending on change of the basic perturbation (perturbation compensator). According to this recommendation, a combined automatic systems is developed, which simultaneously uses the principle of regulation of deviation and perturbation.

To confirm the correctness of the choice of the control law and the parameters of the controller and compensator, on the example of automatic level control system, simulation was performed in the MATLAB / Simulink application package. The use of the main disturbance compensation channel improves the quality of maintenance of the technological parameter within the specified limits in the event of significant disturbances. The obtained simulation results confirm the efficiency of the combined system developed in the work.

Key words: automatic control system, drum boiler, level, vacuum, perturbation, quality, modelling. 